\title{
A Global Review of Monitoring, Modeling, and Analyses of Water Demand in Dairy Farming
}

\author{
Philip Shine ${ }^{1, * \mathbb{C}}$, Michael D. Murphy ${ }^{1}\left(\mathbb{D}\right.$ and John Upton ${ }^{2}$ \\ 1 Department of Process, Energy and Transport Engineering, Cork Institute of Technology, Cork, Ireland; \\ michaelD.murphy@cit.ie \\ 2 Animal and Grassland Research and Innovation Centre, Teagasc Moorepark Fermoy, Co., Cork, Ireland; \\ john.upton@teagasc.ie \\ * Correspondence: philip.shine@cit.ie
}

Received: 13 August 2020; Accepted: 31 August 2020; Published: 3 September 2020

\begin{abstract}
The production of milk must be balanced with the sustainable consumption of water resources to ensure the future sustainability of the global dairy industry. Thus, this review article aimed to collate and summarize the literature in the dairy water-usage domain. While green water use (e.g., rainfall) was found to be largest category of water use on both stall and pasture-based dairy farms, on-farm blue water (i.e., freshwater) may be much more susceptible to local water shortages due to the nature of its localized supply through rivers, lakes, or groundwater aquifers. Research related to freshwater use on dairy farms has focused on monitoring, modeling, and analyzing the parlor water use and free water intake of dairy cows. Parlor water use depends upon factors related to milk precooling, farm size, milking systems, farming systems, and washing practices. Dry matter intake is a prominent variable in explaining free water intake variability; however, due to the unavailability of accurate data, some studies have reported moving away from dry matter intake at the expense of prediction accuracy. Machine-learning algorithms have been shown to improve dairy water-prediction accuracy by $23 \%$, which may allow for coarse model inputs without reducing accuracy. Accurate models of on-farm water use allow for an increased number of dairy farms to be used in water footprinting studies, as the need for physical metering equipment is mitigated.
\end{abstract}

Keywords: dairy; water; review; modelling; water footprint; agriculture

\section{Introduction}

Of the global water supply, $97 \%$ is saline, and thus unsuitable for human consumption. Freshwater, encompassing the remaining $3 \%$, therefore represents earths most valuable natural resource, essential for human and animal consumption, agriculture, ensuring biodiversity and ecosystems, as well as offering hygiene services and a vital commodity used by industry [1]. However, only $0.4 \%$ of the world's total freshwater is readily available as surface water in rivers, lakes, and wetlands, with the vast majority embedded in glaciers, polar ice caps, or groundwater aquifers [2]. In conjunction with a growing population and the resulting increase in agricultural, industrial, and energy requirements, the per capita availability of freshwater is reducing [2]. Thus, water policy is an increasingly topical subject globally, with the introduction of the EU Water Framework Directive (2000/60/EC) and EU Groundwater Directive (2006/118/EC) aiming to improve and protect the water quality of rivers, lakes, groundwater, and transitional coastal waters [3,4]. The EU Groundwater Directive states, "water is not a commercial product like any other but, rather, a heritage which must be protected, defended and treated as such".

The agricultural sector represents the largest consumer of freshwater globally, accounting for approximately $70 \%$ of all global freshwater use [5]. The agricultural sector therefore requires substantial improvements in water-use efficiency and productivity, as the production of agricultural products 
to meet the needs of a growing population is limited by not only land availability, but also the availability of freshwater [2]. The three largest product categories contributing to the global water footprint are cereals $(27 \%)$, meat $(22 \%)$, and dairy products $(7 \%)[6]$. Although the production of dairy products is the third largest contributor, its share may increase over the coming decades, as the global consumption of milk and dairy produce is forecasted to increase by $19 \%$ by 2050 compared to 2005-2007 levels [5]. The increase of dairy herds and consequent milk production comes with its own unique challenges regarding the consumption of freshwater. The magnitude and efficiency (liters of water per dairy cow, liters of water per liter of milk produced, etc.) of water use on dairy farms varies according to a number of factors including, but not limited to, irrigation requirements, type of production system (e.g., grazing or confinement), level of milk production, type of milking system (e.g., conventional or automatic milking system (AMS)), geographical location, and environmental conditions. Thus, understanding variances in water consumption may offer on-farm benefits regarding the protection of public water systems and local freshwater supplies, and allow optimization of infrastructural equipment for a cost-effective water system.

Water consumption incorporates (1) green water, which is the water required for soil moisture due to evapotranspiration; (2) grey water, which is the volume of freshwater required to mitigate a given pollutant load via dilution; and (3) blue water, which is fresh surface and groundwater usage. Direct use of freshwater on dairy farms may be required for yard wash down, milk pre-cooling, hot washing of milking equipment, and cow drinking water as well as miscellaneous usage throughout the farm, and is therefore the most controllable water use by the farmer. An adequate freshwater system is important to ensure the sufficient hydration of dairy cows for good milk production as well as for the sanitation of infrastructural equipment [7]. The direct water demand required will increase along with expanding milk production and may increase to unsustainable levels, potentially depleting groundwater borehole supplies and placing additional pressure on the public water supply [8]. In particular, the water demand may rise dramatically in line with milk production, which may cause local water shortages during periods of scarce rainfall.

It is clear that the production of milk and dairy produce globally must be carried out with considerations regarding water consumption in order to ensure the future sustainability of the dairy industry. Thus, research in this domain will become increasingly important as researchers aim to identify new technologies and methods to improve the water sustainability of dairy farming. However, there has been a lack of secondary research undertaken in this domain to date, particularly related to direct freshwater use. At this point in time, it is important to understand the current state of the research pertaining to dairy-farm water consumption, and to allow for the identification of areas in which future research efforts should be focused to support the future monitoring and sustainability of global milk production. Therefore, this review focused on critically assessing published literature related to the monitoring, prediction modeling, and analysis of water consumption in dairy farming. Although overall water footprinting and life-cycle assessments in the literature are covered, this review places specific emphasis on the water consumption on dairy farms that can be controlled by the farmer, i.e., direct freshwater consumption for plant washing and cow drinking.

This review incorporates three primary components. Section 2 explores research studies focused on dairy water consumption, prediction modeling, and analysis, while Section 3 provides a discussion overview highlighting common trends throughout the dairy water literature prior to Section 4, which provides a concise conclusion to this review.

\section{Dairy Water Consumption}

Water consumption may be categorized as green water, grey water, or blue water. Green water is defined as the infiltrated rainfall in the unsaturated soil layer, while not incorporating green-water run-off recharging groundwater supplies [9,10]. Consumption of green water refers to the usage of precipitation (rainwater), required for the production of pasture, forages, and/or crops (e.g., wheat, 
barley, soybeans), through evapotranspiration, necessary for the manufacturing of feed for animal livestock (i.e., dairy cows) [11,12].

Grey-water consumption refers to the virtual volume of freshwater required to dilute pollutants present in water (due to the manufacturing process) to the required ambient water-quality standards [11,12]. From a dairy production perspective, one source of grey-water consumption might be the dilution of water utilized (and mixed with cleaning products) for cleaning and sanitizing milk bulk tanks and milk harvesting equipment [13]. Thus, grey water is an indicator of water pollution, and is often excluded from water footprint studies as it represents a virtual quantity of water as opposed to an actual water use [14-16]. Lastly, blue water refers to the consumption of freshwater (from groundwater sources, lakes, rivers, or mains supply) that is not immediately returned to the same catchment $[11,12]$. Demand for blue water therefore results in a loss of water from the available freshwater source in a catchment area through evaporation, and returning to either a different catchment area or the sea, or is incorporated into a product. Sources of blue-water demand on dairy farms include the requirement of freshwater for irrigation, cow drinking water, and water for cleaning plant equipment.

The quantities of green, grey, and blue water required in dairy production vary from region to region depending on the frequency of precipitation and the availability of groundwater sources, which will influence both the ability to grow pasture and thus the type of dairy system employed (e.g., grazing or confinement). Although water may be considered a renewable resource, its availability may be considerably limited in certain months of the year due to meteorological and geographical constraints [17]. Thus, understanding the volume of water consumed in dairy farming and the type of water consumed in conjunction with the water availability is significantly important when quantifying the sustainability of dairy production (and all agricultural activities) in a particular region.

There are three primary methods generally employed across agricultural water literature to quantify water sustainability across the entire supply chain (direct and indirect), as described by Ran et al. [18]. These include (1) water-footprint assessments, which quantify the volume of water required to produce a good or service (e.g., liters of water per kg fat and protein-corrected milk (FPCM)). Generally used for global assessments, calculating the water footprint allows for the identification of the point on the supply chain at which water is required and consumed. A synopsis of dairy water-footprint studies is shown in Table 1; (2) life-cycle assessments, which calculate the volume of water required within a defined system boundary may also be adjusted using a water-stress index (WSI) to account for localized water stress where it is consumed. Although very data-intensive, life-cycle assessments allow for the local impact of water usage to be calculated in relation to potential water scarcity during certain periods using a country-/region-specific WSI [19]. The WSI is a dimensionless value ranging from 0 to 1 , measuring the ratio between total annual water withdrawal and total annual water availability, while accounting for seasonal variability in precipitation and flows in a specific country/region; (3) water productivity relates to quantifying water consumption relative to physical or economic outputs. Generally, water-productivity calculations do not separate green- and blue-water consumption, but can help to reduce water footprints substantially by improving overall water productivity, which may be necessary in regions with scarce water supplies.

Global water footprint studies carried out by Mekonnen and Hoekstra [20] estimated country-specific green-, grey-, and blue-water consumption values for a range of farm animals and animal products, distinguishing between different production systems (grazing, industrial, and mixed) while considering the country-specific conditions related to feed-conversion efficiency of the animal, origin of the feed, and feed composition. They estimated a total water-footprint value of $1299 \mathrm{~L}$ of water $\left(\mathrm{L}_{\mathrm{w}}\right) \mathrm{kg}^{-1} \mathrm{FPCM}$, whereby $91 \%$ was attributed to green-water use, $5 \%$ was attributed to grey-water use, and $4 \%$ was attributed to blue-water consumption (Table 1). Water-footprint calculations were carried out across countries worldwide. Estimated water-footprint values for China, the Netherlands, the USA, and India are also shown in Table 1, in conjunction with values from six additional research studies found in the literature $[13,15,16,21-23]$. Two of these additional studies estimated blue-water use values 
of $66 \mathrm{~L}_{\mathrm{w}} \mathrm{kg}^{-1}$ FPCM and $13 \mathrm{~L}_{\mathrm{w}} \mathrm{kg}^{-1}$ FPCM in the Netherlands [16] and South Gippsland, Australia [21], respectively. In the Netherlands case-study farm, $76 \%$ of blue-water consumption was utilized for irrigation, $15 \%$ was required for the production of concentrates, and $8 \%$ for drinking and cleaning services [16]. In Australia, 83\% of total blue-water consumption was utilized on-farm for drinking and cleaning of plant equipment, while the remaining $13 \%$ was associated with the production of farm inputs such as concentrated feed. The considerably larger blue-water footprint in the Netherlands was due to irrigation. Interestingly, without irrigation, the calculated blue-water footprint in the Netherlands was equal to $16 \mathrm{~L}_{\mathrm{w}} \mathrm{kg}^{-1}$ FPCM, which was only $23 \%$ greater than that in Australia without any irrigation system. De Boer et al. [16] also calculated a stress-weighted water-footprint value of $33 \mathrm{~L}_{\mathrm{w}} \mathrm{kg}^{-1} \mathrm{FPCM}$, implying that $1 \mathrm{~kg}$ of FPCM produced on a case-study farm in the Netherlands had an impact on water deprivation equivalent to the direct consumption of $33 \mathrm{~L}$ of water by an average world citizen.

Table 1. Dairy water-footprint assessment $\left(\mathrm{L}_{\mathrm{w}} \mathrm{kg}^{-1}\right.$ fat and protein-corrected milk (FPCM)) studies found in the literature.

\begin{tabular}{ccccccc}
\hline Study & Year & Region & WF $^{*}$ & GW & Grey & BW \\
\hline Mekonnen and Hoekstra [20] $^{1}$ & 2012 & Global Avg. & 1299 & 1185 & 61 & 53 \\
Mekonnen and Hoekstra [20] $^{1}$ & 2012 & IND & 1592 & 1425 & 41 & 126 \\
Mekonnen and Hoekstra [20] $^{1}$ & 2012 & CHN & 1651 & 1438 & 117 & 96 \\
Mekonnen and Hoekstra [20] $^{1}$ & 2012 & NTL & 781 & 683 & 38 & 60 \\
Mekonnen and Hoekstra [20] $^{1}$ & 2012 & USA & 1414 & 1237 & 100 & 77 \\
De Boer et al. [16] & 2013 & NTL & - & - & - & 66 \\
Murphy et al. [15] & 2016 & IRE & 690 & 684 & - & 6 \\
Ridoutt et al. [21] $_{\text {Sultana et al. [22] }}^{1}$ & 2010 & AUS & - & - & - & 13 \\
Palhares and Pezzopane [13] & 2014 & Global Avg. & 1643 & 1423 & 103 & 117 \\
Palhares and Pezzopane [13] & 2015 & BRA (Conv) & 935 & 858 & 73 & 4 \\
Zonderland-Thomassen and & 2015 & BRA (Org) & 785 & 682 & 94 & 9 \\
Ledgard [23] & AUS & 945 & 676 & 260 & 9 \\
Zonderland-Thomassen and & 2012 & AUS & 1084 & 499 & 336 & 249 \\
Ledgard [23] & & & & & \\
\hline
\end{tabular}

${ }^{*} \mathrm{WF}$ = water footprint; $\mathrm{GW}$ = green water; $\mathrm{BW}$ = blue water; Con = conventional farm; Org = organic farm; $\mathrm{FPCM}=$ fat- and protein-corrected milk; Grey = grey water; $\mathrm{CHN}=\mathrm{China}, \mathrm{NTL}=$ the Netherlands; USA = United States of America; IRE = Ireland; IND = India; BRA = Brazil. WF, GW, Grey, and BW values were transformed to $\mathrm{L}_{\mathrm{w}} \mathrm{kg}^{-1}$ FPCM using Equations (A1)-(A3) in Appendix A, and related fat and protein percentage values. ${ }^{1}$ Converted to $\mathrm{L}_{\mathrm{w}} \mathrm{kg}^{-1}$ FPCM using country-specific milk fat and protein percentage values [24].

Green-, blue-, and grey-water-footprint values in milk production were also calculated by Sultana et al. across 72 dairy regions from 48 countries, representing $85 \%$ of the world's milk production [22]. They identified a typical farm for each dairy region, based upon the most common farm size, farming system, production technology, and management practices used in each country. They then used the TIPI-CAL (Technology Impact Policy Impact Calculation) model, based on the principles of the farm-level impact of policy simulations, to estimate water footprints across grazing, intensive, and small-scale dairy farming within each region. The global average calculated by Sultana et al. was equal to $1643 \mathrm{~L}_{\mathrm{w}} \mathrm{kg}^{-1} \mathrm{FPCM}$, composed of $87 \%$ green-water use, $7 \%$ grey-water use, and $6 \%$ blue-water use. Western Europe was found the have the lowest green- and blue-water footprints with averages of 721 and $59 \mathrm{~L}_{\mathrm{w}} \mathrm{kg}^{-1} \mathrm{FPCM}$, respectively. On the other hand, typical small-scale African farming had the highest green-water footprint $\left(4417 \mathrm{~L}_{\mathrm{w}} \mathrm{kg}^{-1} \mathrm{FPCM}\right)$, while the highest blue-water footprint was found in typical Middle East feed-lot farming (295 $\left.\mathrm{L}_{\mathrm{w}} \mathrm{kg}^{-1} \mathrm{FPCM}\right)$ [22,24].

Utilizing data from 24 Irish dairy farms in 2013, Murphy et al. [15] calculated an overall water footprint of $690 \mathrm{~L}_{\mathrm{w}} \mathrm{kg}^{-1}$ FPCM, whereby $85 \%$ was attributed to green-water use for the production of pasture, 10\% was required for imported forage production (hay and silage), $4 \%$ for the production of concentrated feed, and $\sim 1 \%$ for on-farm blue-water use. They also calculated an average stress-weighted 
water footprint of $0.4 \mathrm{~L}_{\mathrm{w}} \mathrm{kg}^{-1} \mathrm{FPCM}$, implying that each liter of milk produced in Ireland contributed $0.4 \mathrm{~L}$ of freshwater consumption by an average world citizen.

Water footprinting is a popular method for attributing water consumption to specific processes throughout the milk-production cycle, as shown in the studies presented in Table 1. It is clear that on average globally, green water is the largest water consumption category in dairy farming, followed by blue-water usage. This was shown by global water-footprinting studies carried out by Mekonnen and Hoekstra [12] and Sultana et al. [22], which found that green water was responsible for $91 \%$ and $87 \%$ of the total water footprint, respectively. Although these studies showed blue-water use to be responsible for between $4 \%$ and $7 \%$ of the total water footprint, depending on the meteorological conditions of a particular region, the overall stress on localized freshwater withdrawals may be considerably high, particularly during periods of little rainfall. Moreover, the potential harm caused by blue-water withdrawals from surface and groundwater sources outweighs the potential harm associated with the consumption of green water sourced from precipitation over agricultural lands, particularly when that blue water is drawn from large underground fossil-water aquifers that have a very low recharge rate. Thus, the following section focuses on aggregating studies in the literature which focused on direct on-farm blue-water consumption.

\subsection{Direct Water Consumption}

Direct water consumption on dairy farms is primarily required for washing and sanitation purposes within the milking parlor, or for dairy-cow drinking water (free water intake (FWI)). Some studies have focused on calculating total direct water use, such as Shine et al. [25], who calculated a total direct water use figure of $7.2 \mathrm{~L}_{\mathrm{w}} \mathrm{kg}^{-1}$ FPCM on Irish dairy farms. However, it is common practice to subcategorize dairy-farm water consumption according to whether consumption takes place within the milking parlor or as FWI. Thus, the following sections highlight and critically assess dairy water literature related to parlor water usage and FWI.

\subsubsection{Parlor Water Consumption}

A description of parlor water consumption figures found in the literature is presented in Table 2. Shine et al. [25] found that $33 \%\left(2.4 \mathrm{~L}_{\mathrm{W}} \mathrm{kg}^{-1}\right.$ milk) of total direct water consumption was used within the milking parlor. Within the milking parlor, the precooling of milk through a plate heat exchanger (PHE) required an average of $1.8 \mathrm{~L}_{\mathrm{w}} \mathrm{kg}^{-1}$ milk, hot-water consumption required $0.15 \mathrm{~L}_{\mathrm{w}} \mathrm{kg}^{-1}$ milk, and water for parlor washdown purposes required $1.3 \mathrm{~L}_{\mathrm{w}} \mathrm{kg}^{-1}$ milk. In the United States, Brugger and Dorsey [26] analyzed the parlor water consumption of a single Ohio dairy farm (herd size $=988$ cows) in 2005. They calculated an average consumption of $0.8 \mathrm{~L}_{\mathrm{w}} \mathrm{kg}^{-1}$ milk with no seasonal variation trend. However, they did note an increase of $0.1 \mathrm{~L}_{\mathrm{w}} \mathrm{kg}^{-1}$ milk during June, July, and August when providing misting to cows to keep their body temperatures down. In Denmark, Brøgger Rasmussen and Pedersen [27] analyzed the parlor water (hot water, cold water, floor washing) consumption of 14 dairy farms which employed an AMS, and three dairy farms with traditional milking systems, between June 2003 and February 2004. Across four AMS brands, Brøgger Rasmussen and Pedersen [27] calculated an average parlor water consumption of $0.4 \mathrm{~L}_{\mathrm{w}} \mathrm{kg}^{-1}$ milk, equal to that consumed by the traditional milking systems. Higham et al. [28] also monitored and analyzed 35 pasture-based dairy farms (herd size range $=160-1150$ cows) in New Zealand over a period of two years (June 2013 to May 2015) and calculated a parlor water usage value of $3.9 \mathrm{~L}_{\mathrm{w}} \mathrm{kg}^{-1}$ milk. In Germany, Krauß et al. [29] analyzed the cleaning water use within a dairy barn (herd size $=176$ cows), autonomously monitoring hourly water usage across two milking systems (a herringbone and an AMS) over 806 days. Krauß et al. [29] estimated a barn-cleaning water consumption value of $0.8 \mathrm{~L}_{\mathrm{w}} \mathrm{kg}^{-1}$ milk for the AMS and a mean of $1.3 \mathrm{~L}_{\mathrm{w}} \mathrm{kg}^{-1}$ milk for the herringbone parlor system. Krauß et al. [29], along with Palhares and Pezzopane [13], highlighted the scarcity of scientific studies of dairy-barn-cleaning water consumption, while also commenting on the lack of detail regarding how cleaning water demand is measured and estimated. 
Table 2. Parlor water consumption values found in the literature.

\begin{tabular}{ccccccc}
\hline Study & Year & Country & $\boldsymbol{n}$ & Farm Type & Measurement & $\mathbf{L}_{\mathbf{w}} \mathbf{~ k g}^{-\mathbf{1}}$ Milk \\
\hline $\begin{array}{c}\text { Brugger and Dorsey [26] } \\
\text { Brøgger Rasmussen and }\end{array}$ & 2006 & USA & 1 & Confinement & Parlor & $0.8^{2}$ \\
$\begin{array}{c}\text { Pedersen [27] } \\
\text { Brøgger Rasmussen and }\end{array}$ & 2004 & DNK & 14 & Confinement (AMS) & Parlor & 0.4 \\
$\quad$ Pedersen [27] & 2004 & DNK & 3 & Confinement & Parlor & 0.4 \\
Higham et al. [28] & 2017 & NZL & 31 & Pasture-based & Parlor & $3.9^{3}$ \\
Krauß et al. [29] & 2016 & DEU & 1 & Confinement (AMS) & Cleaning & 0.8 \\
Krauß et al. [29] & 2016 & DEU & 1 & Confinement & Cleaning & 1.3 \\
Shine et al. [25] & 2018 & IRE & 33 & Pasture-based & Parlor & 2.4 \\
Shine et al. [25] & 2018 & IRE & 50 & Pasture-based & Cleaning ${ }^{1}$ & 1.4 \\
Shorthall et al. [30] & 2018 & IRE & 7 & Pasture-based (AMS) & Parlor & 1.5 \\
Shorthall et al. [30] & 2018 & IRE & 7 & Pasture-based (AMS) & Cleaning ${ }^{1}$ & 0.4 \\
\hline
\end{tabular}

AMS = automatic milking system; USA = United States of America; DNK = Denmark; NZL = New Zealand; $\mathrm{DEU}=$ Germany; IRE = Ireland; FPCM = fat- and protein-corrected milk; $n=$ number of farms assessed.

${ }^{1}$ Water used for cold- and hot-water washdown of milking equipment, the milking parlor, and milk-cooling tank.

${ }^{2}$ Converted to $\mathrm{L}_{\mathrm{W}} \mathrm{kg}^{-1}$ milk using water consumption figure of $28.4 \mathrm{~L}_{\mathrm{w}} \mathrm{cow}^{-1}$ day ${ }^{-1}$ and mean milk production of $80 \mathrm{lbs} \mathrm{cow}^{-1}$ day $^{-1}$. ${ }^{3}$ Converted to $\mathrm{L}_{\mathrm{w}} \mathrm{kg}^{-1}$ milk using water consumption figure of $48.7 \mathrm{~L}_{\mathrm{w}} \mathrm{cow}^{-1} \mathrm{day}^{-1}$ and mean milk production of $12.5 \mathrm{~kg} \mathrm{cow}^{-1}$ day $^{-1}$.

\subsubsection{Free Water Intake}

A description of FWI figures found in the literature is presented in Table 3. FWI has been extensively covered in literature, to the extent that Appuhamy et al. [31] compiled a dataset gathering results from 69 research articles and retrieved 239 FWI treatment means of lactating cows (research articles from North America (47\%), Europe (25\%), and Australia (8\%)), of which $10 \%$ were related to pasture-based dairy-cow diets. When processed, Appuhamy et al. [31] found 55 research articles with useable FWI data to calculate a global figure for lactating cows of $78.4 \mathrm{~L}_{\mathrm{w}} \mathrm{cow}^{-1}$ day $^{-1}$ (mean milk production of $28.1 \mathrm{~kg} \mathrm{cow}^{-1}$ day $^{-1}$ ). Appuhamy et al. [31] also gathered results from 19 research articles related to the FWI figures of dry dairy cows, while utilizing 10 of these to estimate a global figure of $34.0 \mathrm{~L}_{\mathrm{w}} \mathrm{Cow}^{-1}$ day $^{-1}$.

Table 3. Description of FWI values found in literature.

\begin{tabular}{|c|c|c|c|c|c|c|}
\hline Study & Year & Country & $n$ & Measurement & Farm Type & $\mathrm{L}_{\mathrm{w}} \operatorname{cow}^{-1}$ day $^{-1}$ \\
\hline Higham et al. [28] & 2017 & NZL & 35 & Lactating and dry & Grazing & $36.0 *$ \\
\hline Higham et al. [28] & 2017 & NZL & 35 & Lactating and dry & Grazing & 60.0 \\
\hline Appuhamy et al. [31] & 2016 & - & - & Lactating cows & Confinement & 78.4 \\
\hline Appuhamy et al. [31] & 2016 & - & - & Dry cows & Confinement & 34.0 \\
\hline Krauß et al. [29] & 2016 & DEU & 1 & Lactating cows & $\begin{array}{l}\text { Confinement } \\
\text { (AMS) }\end{array}$ & 91.1 \\
\hline Krauß et al. [29] & 2016 & DEU & 1 & Lactating cows & Confinement & 54.4 \\
\hline Cardot et al. [32] & 2008 & FRA & 1 & Lactating cows & Confinement & 83.6 \\
\hline Brugger and Dorsey [26] & 2006 & USA & 1 & Lactating and dry & Confinement & 77.6 \\
\hline
\end{tabular}

* Corrected for leaks; FWI = free water intake; AMS = automatic milking system; NZL = New Zealand; $\mathrm{DEU}=$ Germany; FRA = France; USA = United States of America; $n=$ number of farms assessed.

Krauß et al. [29] calculated a mean drinking-water consumption value of $91.1 \mathrm{~L}_{\mathrm{w}}$ cow $^{-1}$ day $^{-1}$ (mean milk production of $35.5 \mathrm{~kg} \mathrm{cow}^{-1}$ day $^{-1}$ ) for the AMS system, and a mean of $54.4 \mathrm{~L}_{\mathrm{w}}$ cow $^{-1}$ day $^{-1}$ (mean milk production of $25.4 \mathrm{~kg} \mathrm{cow}^{-1}$ day $^{-1}$ ) on a farm that employed a herringbone milking system in Germany. In Ontario, Canada, Robinson et al. [33] also found that dairy farms with AMSs consumed greater volumes of water for drinking compared to free-stall and tie-stall milking operations $(p<0.01)$. Krauß et al. [29] found that 80\% of dairy-cow daily water intake was consumed between 05:00 and 21:00 h, with peak water consumption occurring between 07:00 and 08:00 $\mathrm{h}$ for the cows in AMSs, and between both 07:00 and 08:00 $\mathrm{h}$ and between 17:00 and 18:00 $\mathrm{h}$ for cows on the dairy farm where they were milked via the herringbone system. These peak water-intake times were expected as they 
coincided with milking times [29]. In France, 41 lactating Holstein cows milked via a herringbone parlor system were found to consume $83.6 \mathrm{~L}_{\mathrm{w}} \mathrm{cow}^{-1}$ day $^{-1}$, of which almost $75 \%$ of drinking water was consumed between 06:00 and 19:00 $\mathrm{h}$ [32].

Utilizing a single dairy farm in Ohio, United States, Brugger and Dorsey [26] estimated an overall FWI value of $77.6 \mathrm{~L}_{\mathrm{w}}$ cow $^{-1}$ day $^{-1}$ (mean milk production of $36.2 \mathrm{~kg} \mathrm{cow}^{-1}$ day $^{-1}$ ), reporting an increased water consumption value of $120.7 \mathrm{~L}_{\mathrm{w}} \mathrm{cow}^{-1} \mathrm{day}^{-1}$ in summer due to the increased average ambient temperature. The increased ambient temperature increased the drinking-water requirements of cows and increased the need to provide misting to cows to help reduce body temperature (to promote health and milk-production benefits). This concurred with findings reported by Robinson et al. [33] in which 17 Ontario dairy farms were analyzed and found to consume greater volumes of water during the summer months than in winter $(p<0.05)$. In New Zealand, Higham et al. [28] utilized 35 pasture-based dairy farms to calculate an average drinking-water consumption of $60 \mathrm{~L}_{\mathrm{w}} \mathrm{cow}^{-1}$ day $^{-1}$, although this figure was corrected to $36 \mathrm{~L}_{\mathrm{w}} \mathrm{cow}^{-1}$ day $^{-1}$ when adjusted for leakage (mean milk production of $12.8 \mathrm{~kg} \mathrm{cow}^{-1}$ day $^{-1}$ ). Contradictory to Brugger and Dorsey [26] and Robinson et al. [33], Higham et al. [28] reported reduced total water usage during the summer months.

\subsubsection{Direct Water Consumption Summary}

The literature summarized in this section focused on quantifying both parlor water consumption and FWI on dairy farms through the installation of physical metering equipment over a specified timeframe. As this method is by far the most accurate for calculations related to dairy water consumption, water-footprinting studies often incorporate the physical metering of dairy-farm direct water consumption to measure BW demand. These actual water consumption values are useful for comparing the water footprint of milk between specific regions, cognate studies, or quantifying potential improvements in water usage efficiency over time. However, the installation of metering equipment may require high capital and maintenance costs, can be quite time-consuming, and also limits the number of farms that can be included in a particular study. Thus, literature has covered the development of prediction models for total dairy water consumption as well as both dairy-cow drinking-water consumption and parlor water use. These models provide researchers the ability to make estimations with a reasonable level of accuracy.

\subsection{Dairy Water Prediction Modeling}

Research regarding the prediction modeling of dairy-farm water use has largely focused on predicting the daily dairy-cow FWIs of lactating dairy cows and dry dairy cows. However, research has involved the prediction of water use within the dairy parlor and total direct water consumption, as well as predicting green- and blue-water requirements of milk production. These studies have resulted in the development of a number of regression equations, as shown in Table 4. The current state-of-art approach primarily separates FWI and parlor water usage, using monitored consumption data for either a single or a number of dairy farms.

Regards the prediction of green- and blue-water consumption, Murphy et al. [34] utilized data collected from 25 Irish dairy farms (mean herd size $=126$ cows) between 2014 and 2015 to develop multiple linear regression (MLR) models, as shown in Table 4. Murphy et al. [34] utilized predictive variables related to farm area, milk production, herd size, concentrates, grass growth, imported forages, and metered on-farm freshwater consumption (direct water). Nonsignificant effects $(p>0.05)$ were removed from the MLR through backward elimination to extract variables with high predictive power using SAS software (SAS, 2015). They developed the MLR models on 20 farms and calculated their prediction accuracy on the remaining 5 farms. They found that the MLR model with the input variables of concentrates fed, quantity of grass grown, and imported forages was able to predict dairy-farm green-water consumption to within $11.3 \%$ (relative prediction error (RPE)). Through a standardized regression analysis, the quantity of grass grown was shown to have the largest impact on green-water consumption, with one SD change in grass grown resulting in a $0.92 \mathrm{SD}$ change in 
green-water demand. Regarding blue-water demand, they found that the MLR model using the input variables of concentrates fed and on-farm metered water (direct water) was able to predict dairy-farm blue-water usage to within 3.4\% (RPE). Through a standardized regression analysis, they calculated on-farm metered water as having the largest impact on blue-water usage, with one SD change in on-farm metered water resulting in a 0.95 SD change in blue-water demand.

A large number of variables have been reported to influence direct water use on dairy farms, as shown via the regression models shown in Table 4. The predictive impact of these variables, and the resulting predictive capabilities vary between studies due to differences in farm data, dairy-cow breed, farming practices, research methodologies, and differences in environmental conditions between countries.

\subsubsection{Direct Water Prediction}

Higham et al. [28] utilized metered water data from 35 New Zealand dairy farms (herd size range $=160-1150$ cows) and data related to climatic conditions, farm characteristics, and milk production to develop regression models to predict dairy-farm total direct water demand (drinking plus parlor). They selected model input variables based upon their ability to explain the variability of the observed data. Model development was carried out utilizing 21 variables, including both continuous and categorical data. Input variables were assessed as linear and quadratic terms during model development. The variables (linear or squared terms) with the lowest influence (lowest standardized regression coefficient) on total water consumption were iteratively removed to produce a model with a similar $\mathrm{R}^{2}$ value to the original but with considerably fewer input variables. Model accuracy was then assessed on unseen data using 50-fold cross-validation. Higham et al. [28] found that the regression model with six input variables of maximum ambient temperature, evapotranspiration, radiation, milk solids (MS), milk volume, and whether a rotary or herringbone milking parlor was employed was able to explain $90 \%$ of the overall variability $\left(R^{2}=0.90\right)$. Model coefficients are shown in Table 4 .

Shine et al. [35] also employed MLR modeling to predict dairy water consumption; however, they took a different approach to Higham et al. [28]. As opposed to predicting daily water consumption, they predicted monthly water consumption data remotely monitored on 51 dairy farms throughout the January 2014-May 2016 period in conjunction with farm details related to milk production, stock, farm infrastructure, managerial processes, and environmental conditions. This resulted in 12 individual regression models equations being developed (one for each month), allowing for consumption trends throughout the year to be linearly modeled. In total, 20 dairy-farm variables were assessed for their ability to predict dairy-farm water consumption. The subset of farm variables that maximized the prediction accuracy of unseen water consumption was selected through application of a univariate variable selection technique, all-subsets regression, and 10-fold cross-validation. The most accurate MLR model configuration for water consumption prediction contained six variables: herd size, milk production, the number of parlor units, automatic parlor washing, whether ground water was utilized for precooling in an open-loop system, and whether water troughs were reported to contain leaks. This MLR model was found to predict dairy direct water consumption to within $49 \%$ (RPE), within which, through a standardized regression analysis, milk production, automatic parlor washing, and whether winter building troughs were reported to be leaking were shown to have the largest impacts on water consumption. 
Table 4. Regression models in literature predicting free water intake (FWI), parlor water use (Parlor), total water use (TW), green-water use (GW), and blue-water use (BW).

\begin{tabular}{|c|c|c|c|c|c|}
\hline Study & Year & Unit & Regression Model & $\mathbf{R}^{2}$ & RMSPE \\
\hline Castle and Thomas [37] & 1975 & $\mathrm{FWI}^{\mathrm{a}}$ & $=-15.3+2.53 \times M Y+0.45 \times D M \%$ & 0.73 & $\mathrm{n} / \mathrm{a}$ \\
\hline Little and Shaw [38] & 1978 & FWI ${ }^{a}$ & $=12.3+2.15 \times D M I+0.73 \times M Y$ & 0.73 & $\mathrm{n} / \mathrm{a}$ \\
\hline Murphy et al. [39] & 1983 & $\mathrm{FWI}^{\mathrm{a}}$ & $=16.0+1.58 \times \mathrm{DMI}+0.90 \times \mathrm{MY}+0.05 \times \mathrm{NaI}+1.20 \times \min \mathrm{T}$ & 0.59 & $\mathrm{n} / \mathrm{a}$ \\
\hline Murphy et al. [39] & 1983 & $\mathrm{FWI}^{\mathrm{a}}$ & $=23.0+2.38 \times D M I+0.64 \times M Y$ & 0.42 & $\mathrm{n} / \mathrm{a}$ \\
\hline Stockdale and King [40] & 1983 & FWI $^{\text {a }}$ & $=-9.37+2.30 \times D M I+0.53 \times D M \%$ & 0.58 & $\mathrm{n} / \mathrm{a}$ \\
\hline Holter and Urban [41] & 1992 & FWI ${ }^{b}$ & $=-10.34+0.23 \times D M \%+2.212 \times D M I+0.03944 \times C P^{2}$ & 0.64 & $\mathrm{n} / \mathrm{a}$ \\
\hline Holter and Urban [41] & 1992 & FWI ${ }^{a}$ & $=-32.4+2.47 \times D M I+0.60 \times M Y+0.62 \times D M \%+0.091 \times J D-0.00026 \times J D^{2}$ & 0.69 & $\mathrm{n} / \mathrm{a}$ \\
\hline Dahlborn et al. [42] & 1998 & FWI ${ }^{a}$ & $=14.3+1.24 \times M Y+0.32 \times D M \%$ & 0.67 & $\mathrm{n} / \mathrm{a}$ \\
\hline Meyer et al. [43] & 2004 & $\mathrm{FWI}^{\mathrm{a}}$ & $=26.1+1.30 \times \mathrm{MY}+0.406 \times \mathrm{NaI}+1.516 \times$ mean $\mathrm{T}+0.058 \times$ BodyWeight & 0.60 & $\mathrm{n} / \mathrm{a}$ \\
\hline Cardot et al. [32] & 2008 & FWI ${ }^{a}$ & $=-25.65+1.54 \times D M I+1.33 \times M Y+0.89 \times D M \%+0.57 \times$ minT $-0.30 \times$ Rain & 0.74 & $\mathrm{n} / \mathrm{a}$ \\
\hline Khelil-Arfa et al. [44] & 2012 & FWI $a, b$ & $=-77.6+3.22 \times D M I+0.92 \times M Y-0.28 \times C o n \%+0.83 \times D M \%+0.037 \times$ BodyWeight & 0.92 & $\mathrm{n} / \mathrm{a}$ \\
\hline Khelil-Arfa et al. [44] & 2012 & FWI a. b & $=-41.1+1.54 \times M Y-0.29 \times$ Con $\%+0.97 \times D M \%+0.039 \times$ BodyWeight & 0.86 & $\mathrm{n} / \mathrm{a}$ \\
\hline Appuhamy et al. [31] & 2016 & FWI ${ }^{a}$ & $=-91.1+2.93 \times D M I+0.61 \times D M \%+0.062 \times \mathrm{NaK}+2.49 \times C P \%+0.76 \times$ meanT & $\mathrm{n} / \mathrm{a}$ & $14.4 \%$ \\
\hline Appuhamy et al. [31] & 2016 & FWI ${ }^{a}$ & $=-60.2+1.43 \times \mathrm{MY}+0.064 \times \mathrm{NaK}+0.83 \times \mathrm{DM} \%+0.54 \times$ meanT $+0.08 \times \mathrm{DIM}$ & $\mathrm{n} / \mathrm{a}$ & $17.9 \%$ \\
\hline Appuhamy et al. [31] & 2016 & $\mathrm{FWI}^{\mathrm{b}}$ & $=1.16 \times D M I+0.23 \times D M \%+0.44 \times$ mean $T+0.061 \times$ meanTC $^{2}$ & $\mathrm{n} / \mathrm{a}$ & $12.8 \%$ \\
\hline Appuhamy et al. [31] & 2016 & FWI ${ }^{b}$ & $=0.010 \times$ BodyWeight $+0.32 \times$ DM $\%+0.52 \pm 0.21 \times$ mean $+0.053 \times$ meanTC $^{2}$ & $\mathrm{n} / \mathrm{a}$ & $15.2 \%$ \\
\hline Krauß et al. [29] & 2016 & FWI ${ }^{a}$ & $=-27.94+0.49 \times$ mean $T+3,15 \times M Y$ & 0.67 & $\mathrm{n} / \mathrm{a}$ \\
\hline Murphy et al. [34] & 2017 & $\mathrm{GW}^{\mathrm{a}, \mathrm{b}}$ & $=826 \times C n+419 \times \mathrm{Gr}+498 \times \operatorname{lm} F r$ & $\mathrm{n} / \mathrm{a}$ & $11.3 \%$ * \\
\hline Murphy et al. [34] & 2017 & BW $\mathrm{a}, \mathrm{b}$ & $=-20,392+9.1 \times C n+0.92 \times M W$ & $\mathrm{n} / \mathrm{a}$ & $3.4 \%$ * \\
\hline
\end{tabular}


Table 4. Cont.

\begin{tabular}{|c|c|c|c|c|c|}
\hline Study & Year & Unit & Regression Model & $\mathbf{R}^{2}$ & RMSPE \\
\hline Higham et al. [28] & 2017 & $\log (F W I)^{a, b}$ & $\begin{array}{c}=0.369+0.030 \times \operatorname{maxT}-0.009 \times \text { Rain }+0.0001 \times \text { Rain }^{2}-0.117 \times \text { Evap- } \\
0.008 \times \text { Evap }^{2}+0.041 \times \text { Rad }+0.261 \times \text { MS }-0.001 \times \text { MV }^{2}-0.322 \times \text { Milking- } \\
0.124 \times \text { Milking }^{2}\end{array}$ & 0.92 & $\mathrm{n} / \mathrm{a}$ \\
\hline Higham et al. [28] & 2017 & $\log (\text { Parlor })^{a, b}$ & $\begin{array}{c}=1.168+0.417 \times M S-0.208 \times M^{2}+0.026 \times M V+0.315 \times \text { Milking- } \\
0.021 \times \text { Milking }{ }^{2}-0.301 \times \text { Breed }-0.029 \times \text { CowBale }\end{array}$ & 0.95 & $\mathrm{n} / \mathrm{a}$ \\
\hline Higham et al. [28] & 2017 & $\log (\mathrm{TW})^{\mathrm{a}, \mathrm{b}}$ & $\begin{array}{c}=1.104+0.015 \times \max T-0.011 \times \text { Evap }^{2}+0.016 \times \text { Rad }+0.487 \times M S-0.265 \times M^{2}+ \\
0.025 \times M V+0.051 \times \text { Rotary }\end{array}$ & 0.90 & $\mathrm{n} / \mathrm{a}$ \\
\hline Shine et al. [35] & 2018 & $\mathrm{TW}_{i}$ & 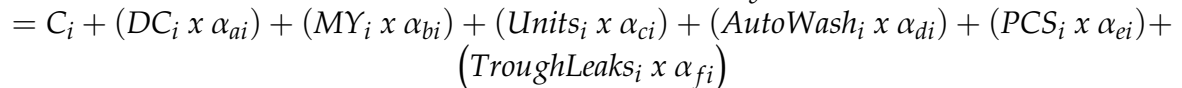 & 0.27 & $49 \%$ * \\
\hline
\end{tabular}

${ }^{\mathrm{a}}$ denotes the water prediction of lactating cows. ${ }^{\mathrm{b}}$ denotes the water prediction of dry cows. $\mathrm{TW}_{i}=$ total water use in month $i$. RMSPE $=$ root-mean-square prediction error as a percentage of average observed value (\%). * denotes relative prediction error $(\mathrm{RPE}(\%)) . \mathrm{n} / \mathrm{a}=$ data unavailable. Ash $\%=$ dietary total ash content $(\%)$; AutoWash $=$ automatic parlor washing $(\mathrm{No}=0$, Yes $=1)$; BodyWeight $=\mathrm{cow}$ weight $(\mathrm{kg}) ;$ Breed $=$ cow breed $(1=$ Friesian, $0.5=$ Friesian-Jersey cross, $0=$ Jersey $) ; \mathrm{C}_{\mathrm{i}}=$ constant value for month $i$; $\mathrm{Cn}=$ concentrates fed $\left(\mathrm{kg} \mathrm{DM}_{\text {year }}{ }^{-1}\right) ; \mathrm{Con} \%=$ proportion of concentrate in diet $(\%$ of DM); CowBale = cow to cluster ratio; $\mathrm{CP}=$ crude protein percentage of dry matter $(\%)$; DC = number of dairy cows; $\mathrm{DIM}=$ day in milk; DM = dry matter $(\mathrm{kg}) ; \mathrm{DM} \%$ = dietary dry matter $(\%) ; \mathrm{DMI}=$ dry matter intake $\left(\mathrm{kg} \mathrm{day}^{-1}\right)$; Evap = Priestly Taylor potential evapotranspiration $(\mathrm{mm}) ; \mathrm{FWI}=$ free water intake $\left(\mathrm{L}_{\mathrm{W}} \mathrm{cow}^{-1}\right.$ day $\left.^{-1}\right) ; \mathrm{Gr}=$ grass grown $\left(\mathrm{kg} \mathrm{DM}\right.$ year $\left.^{-1}\right)$; JD $=$ Julian day; $\mathrm{ImFr}=$ imported forages $\left(\mathrm{kg}^{\mathrm{DM}}\right.$ year $\left.{ }^{-1}\right) ; \operatorname{maxT}=$ maximum temperature $\left({ }^{\circ} \mathrm{C}\right) ;$ meanT $^{2}$ mean temperature $\left({ }^{\circ} \mathrm{C}\right) ;$ meanTC ${ }^{2}=(\text { meanT-16.4 })^{2} ;$ Milking = number of milkings in a day; $\operatorname{minT}=$ minimum temperature $\left({ }^{\circ} \mathrm{C}\right) ; \mathrm{MS}=$ milk solids $($ milk fat + milk protein, $\mathrm{kg}) ; \mathrm{MV}=$ milk

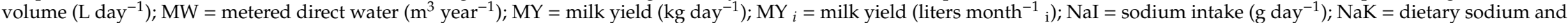
potassium content $\left(\mathrm{mEq} \mathrm{kg}{ }^{-1}\right.$ of DM); Rad = solar radiation $\left(\mathrm{MJ} \mathrm{m}^{2}\right)$; Rain = precipitation $\left(\mathrm{mm} \mathrm{day}^{-1}\right)$; $\mathrm{PCS}=$ open-loop milk pre-cooling system $($ Yes $=0$, No $=1)$; Rotary $=$ milking parlor type (rotary $=1$, herringbone $=0)$; TroughLeaks = leaking troughs $\left(\mathrm{No}=0\right.$, Yes = 1); Units = number of parlor units; $\alpha_{\mathrm{ai}}=$ regression coefficient for variable $a$ and month $i$. 
Shine et al. [36] also looked at the potential to improve the prediction accuracy of Irish dairy-farm direct water consumption by employing various machine-learning algorithms. Using identical data to Shine et al. [25], Shine et al. [36] assessed the applicability of a classification and regression tree (CART) algorithm, a random forest ensemble algorithm, an artificial neural network and a support vector machine algorithm to predict dairy-farm water consumption. They found that the random forest algorithm maximized the prediction accuracy of dairy-farm water consumption, resulting in an RPE value of $38 \%$ (an improvement of $23 \%$ compared to MLR modeling). Thus, machine-learning algorithms failed to reduce the prediction error to a useable level (less than $20 \%$ ). As the dry matter intake (DMI), live weight, and sodium intake influence cows' drinking-water intake, it is feasible that not considering these, along with individual farm effects (leaks, location of water troughs, etc.) and factors that affected the production of fresh pasture, contributed to the poor prediction accuracy of dairy-farm water consumption using machine-learning algorithms.

\subsubsection{Parlor Water Prediction}

Regarding parlor water demand, Higham et al. [28] built a regression model with five input variables, including milk volume, MS, number of milkings per day, body weight, and the number of cows per milking unit, which explained $95 \%$ of the variability $\left(R^{2}=0.95\right)$. The model's coefficients are shown in Table 4.

In Ontario, Canada, a balance equation for predicting parlor water consumption was developed by combining four scientific research studies and was embedded as a component of the Ontario Ministry of Agriculture, Food and Rural Affairs' Nutrient Management software program [45]. The balance equation was developed using empirical usage parameters calculated by Cuthbertson et al. [46], House et al. [47], Robinson et al. [33], and Harner et al. [48] to linearly predict the water requirements of six dairy-parlor processes [49]. House et al. [47] collected data on 29 dairy farms over three years (2011-2013) and Robinson et al. [33] monitored the parlor water consumption of 17 dairy farms throughout a 20 month period (May 2013-Dec 2014), while Cuthbertson et al. [46] surveyed 308 Ontario dairy farms and washing water volumes recorded based on supplier calculations. The Ontario dairy-farm parlor water balance equation comprised six components, as detailed by Piquette [49]: (1) a mandatory base washing water usage value reflecting the type of milking system (tie stall, parlor, robotic with brush teat cleaning or robotic with water teat cleaning) multiplied by the number of lactating cows, as developed from Cuthbertson et al. [46]; (2) a plate-cooler volume figure calculated based on a milk-production value of $30 \mathrm{~L}_{\mathrm{m}} \mathrm{cow}^{-1}$ day $^{-1}$ and $1.5 \mathrm{~L}_{\mathrm{w}} \mathrm{L}_{\mathrm{m}}{ }^{-1}$ consumed for milk precooling, for water not recycled within the milking parlor; (3) a bulk tank-cleaning water value based on milk production of $30 \mathrm{~L}_{\mathrm{m}}$ cow $^{-1}$ day $^{-1}$ and $0.05 \mathrm{~L}_{\mathrm{w}} \mathrm{L}_{\mathrm{m}}{ }^{-1}$ consumed for bulk tank-washing purposes reflective of whether the bulk tank system did or did not have a washing system (no $=0 \mathrm{~L}_{\mathrm{w}}$; yes $=1.5 \mathrm{~L}_{\mathrm{W}} \times$ no. of lactating cows); (4) a parlor-wash water usage for conventional parlor milking systems $\left(17 \mathrm{~L}_{\mathrm{w}} \mathrm{day}^{-1}\right.$ $\times$ no. of lactating cows) and robotic farms $\left(11\right.$ or $17 \mathrm{~L}_{\mathrm{w}}$ day $^{-1}$ (depending upon teat cleaning system) $\times$ no. of lactating cows); (5) a miscellaneous water usage value of $4 \mathrm{~L}_{\mathrm{w}} \mathrm{cow}^{-1}$ day $^{-1}$, as recommended by House et al. [47]; and (6) a heat abatement value of $18.5 \mathrm{~L}_{\mathrm{w}}$ multiplied by the number of abatement days, as calculated by Harner et al. [48]. Piquette [49] employed the Ontario dairy-farm parlor water balance equation as part of a study aimed at calculating the water footprint of dairy farming in Eastern Ontario. However, this system had limitations regarding its inability to estimate parlor water usage on non-milking days and its simplistic nature, as each water usage process was included independently. More specifically, each model component of the Ontario dairy-farm parlor water balance equation is a separately calculated coefficient, meaning that potential relationships between the number of lactating cows, farm processes and system infrastructure are not accounted for.

In Australia, a similar approach to that of Piquette [49] was taken by the Department of Primary Industries (DPI) [50] using a mechanistic approach combined with empirical statistical data, as summarized by Callinan et al. [51]. The model was developed to estimate dairy barn water consumption, including yard cleaning, milk-cooling, parlor cleaning, cluster and platform sprays, 
milking-machine cleaning, and miscellaneous (yard sprinklers, fly mist sprays, washing ancillary milking equipment after milking, calf-feeding equipment). This method for estimating barn water consumption required a large amount of infrastructure data such as water pump flow rates, washdown water-container volume, the number of days the yard was cleaned annually, the average length of time the plate-cooler water was running per day at lactation and the number of days the plate cooler is used annually. Although DPI [50] failed to highlight model predication accuracy figures, this approach is an inefficient method of water consumption prediction on a large scale due to the magnitude of input variables required for predictions.

\subsubsection{Free Water Intake Prediction}

To explain variances in daily FWI, variables related to environmental conditions (temperature $\left({ }^{\circ} \mathrm{C}\right)$, precipitation $(\mathrm{mm})$, evapotranspiration $(\mathrm{mm})$ ), dietary consumption (dietary ash content $(\%)$, dry matter intake (DMI, $\left.\mathrm{kg} \mathrm{day}^{-1}\right)$, percentage of dietary dry matter $(\mathrm{DM} \%, \%)$, protein percentage of diet $(\%)$, sodium intake $\left(\mathrm{g} \mathrm{day}^{-1}\right.$ ) etc.), dairy-cow characteristics (body weight, breed, days in milk), and milking infrastructure (rotary or herringbone milking parlor), as well as factors such as milk yield, the number of cows per milking cluster, the number of milkings per day, grass growth, and Julian day number have been employed. Of the literature contained in Table 4, 18 of the 22 studies developed prediction models for dairy-cow FWI with a mean $\mathrm{R}^{2}$ value of 0.70 (range; $0.42-0.92$ ), i.e., capable of explaining $70 \%$ of the variability of FWI of dairy cows. These studies were focused on explaining the variability of FWI of dairy cows as opposed to developing prediction models. Thus, the accuracy $\left(R^{2}\right)$ values of these MLR models were calculated using data used for the development of the MLR coefficients (seen data). Of these, $61 \%$ (ten models) included DMI as part of the final developed MLR model, a result linked to the very strong influence of DMI on FWI for both lactating and dry dairy cows $[31,41,44]$. These ten studies had a mean DMI multivariate regression coefficient value of 2.19 (range $=1.16-3.22$ ) suggesting that on average, a $1 \mathrm{~kg}$ increase in DMI results in an increase in FWI of $2.19 \mathrm{~L}$.

As highlighted by Appuhamy et al. [31], DMI may not be routinely available on dairy farms for use in predicting drinking-water consumption. Although regression models have been developed without DMI [37,42-44], Appuhamy et al. [31] investigated the impact of excluding DMI as an independent variable for FWI prediction for lactating and dry cows using the same set of dairy farms, as accurate DMI data are often unavailable. Variables considered included DMI, milk production, body weight, number of days in milk, DM\%, and concentrations of sodium and potassium in diet. Regarding the FWI of lactating cows, they developed a regression model (with DMI included) capable of predicting FWI to within $14.4 \%$ (root-mean-square prediction error (RMSPE)). When DMI was excluded, a different subset of prediction variables were selected (to minimize error), whereby the prediction error increased to $17.9 \%$ (RMSPE). Regarding the FWI of dry cows, they developed a regression model (with DMI included) capable of predicting FWI to within $12.8 \%$ (RMSPE), increasing to $15.2 \%$ when DMI was excluded, and new subset of variables utilized. They highlighted that the regression models developed without DMI as an input variable resulted in an increased impact of the DM\% consumed, and that $\mathrm{DM} \%$ represents an easier metric for dairy farmers to calculate.

Of the 18 models developed for predicting the FWI of dairy cows, 12 models included milk production $\left(\mathrm{kg} \mathrm{cow}^{-1} \mathrm{day}^{-1}\right)$ as a predictive variable, whereby on average, an increase in milk production of $1 \mathrm{~kg} \mathrm{cow}^{-1} \mathrm{day}^{-1}$ resulted in an increased FWI of $1.36 \mathrm{~L}$ (range $=0.60-3.15 \mathrm{~L}$ ). Similarly, 11 models included DM\% as an input variable with an average regression coefficient value of 0.53 (range $=0.23-0.97$ ), suggesting that a $1 \%$ increase in the DM\% of a cow's diet results in an increase in FWI of $0.53 \mathrm{~L}$. These regression coefficients were calculated across multiple different time frames ranging from less than one week [38,41] to 806 days [29], using different cow breeds across both lactating and drying-off periods.

Higham et al. [28] utilized data related to climatic conditions, farm characteristics, and milk production to develop regression models to predict dairy-farm drinking-water use, as shown in Table 4 . They calculated that $26 \%$ of stock drinking water was lost through leakage throughout the water 
distribution system; thus, stock drinking water was adjusted using the minimum night flow leak estimation method [52,53]. This method subtracted an average $15 \mathrm{~min}$ resolution night flow water usage (between 00:00 and 03:00 h) from the daytime stock drinking-water volumes. They suggested that due to similar uncorrected drinking-water values being calculated in both New Zealand and Ireland, water leakage in Ireland may be in a similar range. They found that a regression model with seven input variables, including maximum ambient temperature, rainfall, evapotranspiration, radiation, MS, milk volume, and number of milkings carried out per day, explained $92 \%$ of the variability $\left(R^{2}=0.92\right)$ of corrected daily stock drinking water.

\subsubsection{Dairy Water Prediction Summary}

Research regarding water utilization on dairy farms has largely focused to date on modeling the FWI of dairy cows, although research has also involved the modeling of parlor water usage and totalized dairy water consumption. The prediction modeling methods used vary from MLR and polynomial regression to machine-learning algorithms to quantify water consumption. The aim of modeling the FWI of dairy cows in literature is to quantify the variability of FWI that can be explained by the variables considered in each study, as opposed to developing prediction models. Thus, recent studies have focused on developing models to predict dairy total, FWI, and parlor water consumption by assessing model prediction accuracy on unseen data [28,35]. For example, Higham et al. [28] developed prediction models using variables related the environmental conditions, milk production, and farm practices (that could be attained on a large scale). However, their models have yet to be employed to conduct a water analysis (i.e., to assess the impact of future weather conditions or varying farm practices on dairy-cow FWI and/or total or parlor water consumption). However, statistical analyses have been carried out to assess the dairy-farm variables, which have the greatest impact on dairy-farm water consumption.

\subsection{Dairy Water Analyses}

Literature reports indicate that direct water consumption depends upon climatic conditions such as precipitation, air temperature, and exposure to sunlight; factors such as milk production (drinking water for cows in milk), percentage of dry matter intake (DMI), PHE water use and re-use; and cleaning procedures and miscellaneous use throughout the farm $[47,54,55]$. Concurrently, depending upon the farming strategies employed, concerns regarding water usage may include the sizing of boreholes, the sizing of water pumps and piping, the electricity costs of pumping, the size of the manure storage and the potential volume of manure to handle (wastewater used for the washing of parlor equipment going to manure storage), the potential for the pollution of waterways, and effects on neighbors' wells [26].

Precooling milk via water through a plate cooler may reduce milk-cooling energy requirements by up to $50 \%$ [56,57]. However, careful consideration must be given to the financial and environmental impact of this utilization of water, as discussed by Murphy et al. [58]. Teagasc [7] noted the imbalance between average parlor water consumption and the cumulative consumption of precooling, hot-water, and washdown-water usage due to different farms employing different precooling strategies. More specifically, many dairy farmers recycle water utilized for milk precooling for yard washdown purposes or for animal drinking water (provided the water was at an adequate bacterial level). Concurrently, some farmers precool milk without recycling water, while others may not employ any milk precooling strategies. As a result, the milk precooling methodology employed on a dairy farm will impact overall parlor water consumption (as well as milk-cooling-related energy consumption) depending upon factors such as plate-cooler water-to-milk ratio, yard wash-down hose type, the size of the parlor, plate-cooler size, washdown water tank volume, etc.

Shine et al. [25] also conducted a detailed statistical analysis of dairy-farm direct water consumption to determine key relationships between dairy-farm characteristics as well as potential differences between categories of dairy farms. A correlation analysis found water consumption to be largely 
correlated with milk production, and moderately correlated with herd size and the number of lactating cows. In comparison to correlations found with electricity consumption, Shine et al. [25] found reduced correlation strengths for water, which suggested that water was less dependent on milk production and stock numbers and more dependent on managerial processes, environmental conditions, and farm infrastructure. They found that employing groundwater for milk precooling in an open-loop system increased parlor water usage by $41 \%$ on average, compared to farms which did not precool. More specifically, dairy farms which recycled milk precooling water had a $119 \%(p=0.02)$ greater washdown water consumption than those without precooling facilities. Similarly, farms which recycled milk precooling water consumed $137 \%(p=0.08)$ more water for washing purposes than those which did not recycle. This suggested that although farms recycled PHE water throughout the farm, use of this magnitude of water may be unwarranted for washdown purposes. They also suggested potential benefits to closed-loop milk precooling systems, allowing for a greater water-to-milk ratio as water conservation is not an issue. This would reduce milk-cooling energy use as well as reducing parlor water consumption, as only the volume of water required for washing purposes is used.

Callinan et al. [51] conducted a statistical analysis regarding daily parlor water consumption using surveyed parlor water consumption volumes and farm-practices information from over 1500 dairy farms. These farms were located in Victoria, Australia (regions: Gippsland, Northern Victoria, and Southwest Victoria) and were monitored from January 2001 to February 2009. Victoria is a relatively intensive dairy-farming region, using 53\% of Australia's irrigated land and comprising $71 \%$ of the Australian dairy industry, putting major stress on the region's water supplies [59]. A significance level of 0.05 ( $p<0.05$ unless otherwise stated) was used throughout the statistical report to analyze water consumption according to region, herd size, day number, dairy-parlor type, (rotary (rotating circular milking platform), double-up herringbone and swing-over herringbone), dairy size, and yard wash type (flood, hose, or hydrant). Rotary milking parlors are rotating circular milking platforms which attach and detach milking cluster at each full rotation, meaning that rotary parlors can allow for farmers to manage a large number of dairy cows at a time [60]. A double-up herringbone parlor has a milking cluster available at each cow space with a milking line available on each side of the parlor. Swing-over herringbone milking parlors utilize one milk-harvesting cluster between a pair of adjacent cows [60]. Callinan et al. [51] found a statistically significant positive relationship between daily water use and herd size $(p<0.001)$. Concurrently, a near-significant $(p=0.07)$ reduction in water consumption per cow $\left(\mathrm{L}_{\mathrm{w}} \mathrm{cow}^{-1}\right)$ throughout the analysis period was calculated, highlighting the potential requirement of day number as an explanatory variable in statistical models. Regarding the multiple Australian regions analyzed, Callinan et al. [51] found that water use per day and water use per day per cow $\left(\mathrm{L}_{\mathrm{w}}\right.$ day $\left.^{-1} \mathrm{cow}^{-1}\right)$ were significantly (both $p<0.001$ ) associated with the region (Northern Victoria $>$ Gippsland $>$ Southwest Victoria). Concurrently, water use per day ${ }^{-1}$ and water use per day per cow were also significantly (both $p<0.01$ ) associated with dairy type (rotary $>$ swing-over herringbone $>$ double-up herringbone). This result was similar to that found by Higham et al. [28] whereby parlor water usage was greater for rotary milking parlor systems when compared to herringbone systems. Regarding the recycling of used plate-cooler water, a significantly greater proportion of farms with swing-over parlors recycled plate-cooler water compared to farms with rotary and double-up parlors. Finally, regarding yard washdown, Gippsland had significantly more farms that employed hoses for yard washdown compared to the Northern or Southwest farms, while farms which had rotary parlors had significantly more flood yard washdown systems than double-up or swing-over.

Khan et al. [59] reported on historical trends and future prospects of the water use on Australian dairy farms. Khan et al. [59] highlighted growing pastures, dairy shed operations, and cattle drinking water as the three main components of dairy-farm water use in Australia; however, the proportions may vary according to precipitation influencing the requirement for irrigation. Khan et al. [59] reported a value between 2.5 and 8.5 million liters of water required to sustain pasture growth and dairy-farm operations per cow per year (assuming industrial milk production of $5231 \mathrm{~L}$ per cow per year), highlighting the need to plan for a future with less water availability due to climate change. 
It is clear that an ample body of literature focusing on the analysis of water consumption on dairy farms is available. Both studies of Callinan et al. [51] and Shine et al. [25] found statistically significant relationships between dairy-farm water consumption and infrastructural equipment. However, as dairy-farming practices and environmental conditions vary from country to country, a similar research methodology statistically assessing water utilization on dairy farms internationally is required to further understand the factors that impact dairy-farm water consumption. These analyses are highly beneficial to quantifying the volumetric impact associated with particular water-system technologies.

\section{Discussion and Perspective}

The monitoring of dairy-farm water consumption is well documented throughout the literature, as presented in this review article. However, comparisons between cognate studies can be difficult when equivalent KPIs and prediction accuracy metrics are not used. For example, when reporting dairy water monitoring research results, the most common KPI is $\mathrm{L}_{\mathrm{w}} \mathrm{cow}^{-1} \mathrm{day}^{-1}$. However, results in $\mathrm{L}_{\mathrm{W}}$ cow $^{-1}$ day $^{-1}$ cannot easily be compared to results of other studies that report consumption in terms of water usage per liter of water, $\mathrm{kg}^{-1} \mathrm{FPCM}, \mathrm{kg}^{-1} \mathrm{ECM}$, and $\mathrm{kg}$ milk. Concurrently, it is difficult to compare the latter set of usage consumption metrics with each other without the reporting of fat and protein percentage values of the milk production to allow for an effective comparison between international studies. It is clear that the reporting of dairy water consumption in literature should be done so in a comprehensive manner to allow for the easy comparison between studies in the domain. In the absence of studies of specific milk fat and protein values, country-/region-specific values reported by the FAO may be a suitable replacement [24].

Some studies, such as Murphy et al. [15], have calculated water-footprint figures by utilizing a relatively small sample of dairy farms compared to cognate studies (24 dairy farms). For example, Ridoutt et al. [61] calculated the water footprint of dairy farming in Australia using a sample of 75 dairy farms, while and Zonderland-Thomassen et al. [23] utilized 167 dairy farms to calculate the water footprint of dairy farms in New Zealand. However, both Ridoutt et al. [61] and Zonderland-Thomassen et al. [23] calculated stock drinking- and milking-shed water requirements based upon averaged values calculated in benchmark studies [51,62], as opposed to physical metering of on-farm direct water consumption as was carried out by Murphy et al. [15]. This underscores the importance and potential usefulness of developing dairy water prediction models, as these models complement water-footprinting studies by offering a means to estimate direct on-farm water consumption, mitigating the need of high capital investment for the purchasing, installation, and maintenance of metering equipment. However, when establishing research methodologies, researchers must consider balancing the number of farms to be included in a particular study and the accuracy of the data collected for analysis. More specifically, researchers must consider either analyzing a large number of farms using estimated data (generated using modeling methods) or analyzing a small number of farms using accurate data (collected using metering equipment). Researchers may also consider the option of acquiring accurate consumption data for a small number of farms representative of a larger dairy farm population in order to develop a model which can in turn be used to predict on-farm direct dairy water consumption. This model may then be utilized for estimating direct on-farm water usage values, and inputted to water-footprinting studies of the larger population.

Numerous prediction and analysis methodologies have been employed to predict dairy-farm direct water consumption. The development of prediction models to predict dairy-farm water consumption has generally separated FWI and parlor water usage, using monitored consumption data for either a single or a number of dairy farms. However, with the exception of Higham et al. [28], studies using the calculation of MLR equations to predict FWI have focused on understanding the variances in FWI as opposed to developing models for predicting later FWI. Thus, $\mathrm{R}^{2}$ values are calculated based on observed data (i.e., the same data used to derive model coefficients). Although useful for determining the variance of FWI due to particular variables (such as DMI, MY, etc.), presenting $R^{2}$ values of predictions made using observed data may lead to greatly overestimating future prediction accuracy. 
More recently, the development of models to predict dairy water consumption has moved towards developing prediction models utilizing "easily attainable" farm variables that may be collected on a large scale without the use of specialized equipment $[28,31,35,36]$. Careful consideration must be given when developing empirical models, as researchers run the risk of overestimating their prediction accuracy. To reduce the risk of overestimating prediction accuracy, techniques such as k-fold cross-validation are generally employed throughout the literature to estimate models' prediction capability on unseen data.

Balancing coarse input variables with acceptable prediction accuracy is difficult when using standard regression methods such as MLR. Thus, current work in this domain has applied machine-learning algorithms to improve the prediction accuracy when compared to state-of-the-art MLR modeling methods. However, further improvement is required to achieve greater prediction accuracies that would ensure confidence in and usefulness of model outputs prior to their adoption. Further work may look towards applying a larger range of machine-learning algorithms to dairy-farm direct water consumption data collected internationally, potentially using deep-learning algorithms if/when applicable (large numbers of data points would be required). Concurrently, the development of a global database containing international dairy water consumption figures and descriptive variables could be developed, and models built to generate a global dairy water model. If such a model were to be developed, each country would need to select a cohort of dairy farms that are representative of the country's dairy-farm demographic. These farms' water consumption levels could then be monitored in conjunction with farm characteristics, managerial strategies, and environmental data, and all collected data shared to a central database for model development. This would greatly reduce any financial cost associated with calculating the water consumption of dairy farms globally, as well as offering a means for international comparison. In conjunction with national surveys carried out throughout each country (to collect data required for water models), such a model would offer countries the opportunity to continually monitor dairy water consumption per liter of milk while also assessing the continual impact of various strategies aimed at reducing water use on dairy farms.

\section{Conclusions}

Scientific studies related to the use of water on dairy farms were identified and reviewed with respect to water monitoring, modeling, and analysis, placing a specific focus on studies related to on-farm total water usage, parlor usage, and free water intake (FWI) (e.g., cow drinking water). From reviewing the literature, it is clear that further studies focusing on water consumption within the milking parlor are required internationally. Additionally, future studies should consider the following three points to ensure best practice:

1. When monitoring of on-farm water use is carried out, monitoring equipment should be installed on each of the main water-consuming processes (i.e., sub-metered) to allow each component to be analyzed independently, in order to provide a greater understanding of the processes that have the greatest impact on direct on-farm water use.

2. When calculating key performance indicators, multiple units should be reported to improve their interpretation and ensure they can easily be included in cognate studies. This would reduce rounding and/or transformation errors when calculating key performance indicators across the literature. At a minimum, study-specific milk fat and protein percentage values should be reported to allow for their conversion to any key performance indicator.

3. When developing empirical prediction models, a cohort of study farms should be selected to represent the overall population of a region/country (based on which future predictions will be made). As much as possible, this cohort should cover the range and distribution of farm sizes, different infrastructural equipment employed, and managerial procedures used while being equally distributed throughout the region. 
Considering these three points will help to futureproof studies in the dairy water domain and to ensure more robust analyses, with easily transferrable results that may be compared with those of future cognate studies. Additionally, increasing our understanding of dairy water consumption through statistical analyses and empirical modeling will yield an increased confidence in predictions, improving the attractiveness of empirical models as an alternative to physical metering. As well as removing time and monetary requirements associated with the physical metering of water use, these models may also offer a virtual environment whereby nonlinear impacts of changes to farm practices and equipment on dairy water use may be quantified and used by researchers, farmers, and/or policy-makers when making decisions related to dairy water consumption internationally.

Author Contributions: Conceptualization, P.S. and M.D.M.; methodology, P.S. and J.U.; data curation, P.S., J.U.; writing —original draft preparation, P.S.; writing—review and editing, P.S., J.U., M.D.M.; visualization, P.S.; project administration, M.D.M.; funding acquisition, P.S. and M.D.M. All authors have read and agreed to the published version of the manuscript.

Funding: This work has been funded by the Sustainable Energy Authority of Ireland under the SEAI Research, Development \& Demonstration Funding Program 2018, Grant number 18/RDD/317.

Conflicts of Interest: The authors declare no conflict of interest.

\section{Appendix A}

A range of usage metrics relating to milk analyses are utilized throughout the dairy water consumption literature. These include: liters of milk $\left(L_{m}\right)$, kilograms of milk $\left(\mathrm{kg}_{m}\right)$ (Equation (A1)), fat- and protein-corrected milk (FPCM) (Equation (A2)) [63], and energy-corrected milk (ECM) (Equation (A3)) [64]. The units of FPCM and ECM are commonly utilized for international comparisons as this ensures a fair evaluation between farms with different breeds or feed regimes [63]. However, studies utilizing different usage metrics may be compared through reporting of milk data variables such as the mean percentage of fat $(\%$ or $\mathrm{g} / \mathrm{kg})$, the percentage of protein $(\%$ or $\mathrm{g} / \mathrm{kg})$, and/or the amount of lactose $(\mathrm{g} / \mathrm{kg})$, depending on the key performance indicator required.

$$
\begin{gathered}
\left.k g_{m}=L_{m} x \text { (milk density }\right) \\
F P C M=k g_{m} x((0.1226 x \% \text { Fat })+(0.0776 x \% \text { Protein })+0.2534) k g \\
E C M=L_{m} x \frac{((0.383 x \% \text { Fat })+(0.242 x \% \text { Protein })+0.7832)}{3.1138} k g
\end{gathered}
$$

where milk density equals $1.03 \mathrm{~kg}$ per liter of milk, $L_{m}$ is the volume of milk in liters, \%Fat is the percentage of fat in milk, and \%Protein is the percentage of protein in milk.

\section{References}

1. Koehler, A. Water use in LCA: Managing the planet's freshwater resources. Int. J. Life Cycle Assess. 2008, 13, 451-455. [CrossRef]

2. UN Environment. GEO-6-Healthy Planet Healthy People; Cambridge University Press: Cambridge, UK, 2019. [CrossRef]

3. European Union. Directive 2000/60/Ec Of The European Parliament and of the Council of 23 October 2000 Establishing a Framework for Community Action in the Field of Water Policy. Off. J. Eur. Commun. 2000, L269, 1-93. Available online: https://eur-lex.europa.eu/legal-content/EN/TXT/?uri=celex:32000L0060 (accessed on 2 September 2020).

4. European Union. Directive 2006/118/EC of the European Parliament and of the Council of 12 December 2006 on the Protection of Groundwater against Pollution and Deterioration. Off. J. Eur. Commun. 2006, 19, 19-31. Available online: http://eur-lex.europa.eu/legal-content/EN/TXT/?uri=CELEX:32006L0118 (accessed on 2 September 2020). 
5. Bruinsma, J.; Alexandratos, N. World Agriculture Towards 2030/2050: The 2012 Revision. ESA Work Pap No 12-03 2012:44-44. Available online: http://www.fao.org/docrep/016/ap106e/ap106e.pdf (accessed on 2 September 2020).

6. Mekonnen, M.M.; Hoekstra, A.Y. The green, blue and grey water footprint of crops and derived crop products. Hydrol. Earth Syst. Sci. Discuss. 2011, 8, 763-809. [CrossRef]

7. Teagasc. Dairy Farm Infrastructure Handbook 2017. Available online: https://www.teagasc.ie/media/ website/publications/2017/Dairy-Farm-Infrastructure-Handbook-Moorepark2017-(V3).pdf (accessed on 2 September 2020).

8. O'Connor, D.; Kean, M. Future Expansion of the Dairy Industry in Cork: Economic Benefits and Infrastructural Requirements 2014. pp. 53-55. Available online: http://mathematics.cit.ie/contentfiles/DairyIndustry_ InfrastructureReportJan27w.pdf (accessed on 2 September 2020).

9. Falkenmark, M.; Rockström, J.; Karlberg, L. Present and future water requirements for feeding humanity. Food Secur. 2009, 1, 59-69. [CrossRef]

10. Falkenmark, M.; Rockström, J. The new blue and green water paradigm: Breaking new ground for water resources planning and management. J. Water Resour Plan Manag. 2006, 132, 129-132. [CrossRef]

11. Hoekstra, A.Y.; Chapagain, A.K.; Aldaya, M.M.; Mekonnen, M.M. The Water Footprint Assessment Manual-Setting the Global Standard, 2nd ed.; Earthscan Ltd.: London, UK, 2011.

12. Mekonnen, M.M.; Hoekstra, A.Y. The Green, Blue and Grey Water Footprint of Farm Animals and Animal Products. Value of Water Research Report Series No. 48. vol. 2; UNESCO-IHE Institute for Water Education: Delft, The Netherlands, 2010.

13. Palhares, J.C.P.; Pezzopane, J.R.M. Water footprint accounting and scarcity indicators of conventional and organic dairy production systems. J. Clean Prod. 2015, 93, 299-307. [CrossRef]

14. Ercin, A.E.; Aldaya, M.M.; Hoekstra, A.Y. The water footprint of soy milk and soy burger and equivalent animal products. Ecol. Indic. 2012, 18, 392-402. [CrossRef]

15. Murphy, E.; De Boer, I.J.M.; van Middelaar, C.E.; Holden, N.M.; Shalloo, L.; Curran, T.P.; Upton, J. Water footprinting of dairy farming in Ireland. J. Clean Prod. 2017, 140, 547-555. [CrossRef]

16. De Boer, I.J.M.M.; Hoving, I.E.; Vellinga, T.V.; Van De Ven, G.W.J.J.; Leffelaar, P.A.; Gerber, P.J. Assessing environmental impacts associated with freshwater consumption along the life cycle of animal products: The case of Dutch milk production in Noord-Brabant. Int. J. Life Cycle Assess. 2013, 18, 193-203. [CrossRef]

17. Hoekstra, A.Y.; Chapagain, A.K.; Aldaya, M.M.; Mekonnen, M.M. Water Footprint Manual State of the Art 2009; Water Footprint Network: Enschede, The Netherlands, 2009.

18. Ran, Y.; Lannerstad, M.; Herrero, M.; Van Middelaar, C.E.; De Boer, I.J.M. Assessing water resource use in livestock production: A review of methods. Livest. Sci. 2016, 187, 68-79. [CrossRef]

19. Pfister, S.; Koehler, A.; Hellweg, S. Assessing the environmental impacts of freshwater consumption in LCA. Environ. Sci. Technol. 2009, 43, 4098-4104. [CrossRef] [PubMed]

20. Mekonnen, M.M.; Hoekstra, A.Y. A global assessment of the water footprint of farm animal products. Ecosystems 2012, 15, 401-415. [CrossRef]

21. Ridoutt, B.G.; Williams, S.R.O.; Baud, S.; Fraval, S.; Marks, N. Short communication: The water footprint of dairy products: Case study involving skim milk powder. J. Dairy Sci. 2010, 93, 5114-5117. [CrossRef] [PubMed]

22. Sultana, M.N.; Uddin, M.M.; Ridoutt, B.G.; Peters, K.J. Comparison of water use in global milk production for different typical farms. Agric. Syst. 2014, 129, 9-21. [CrossRef]

23. Zonderland-Thomassen, M.A.; Ledgard, S.F. Water footprinting-A comparison of methods using New Zealand dairy farming as a case study. Agric. Syst. 2012, 110, 30-40. [CrossRef]

24. FAO; FAOSTAT. New Food Balanc 2020. Available online: http://www.fao.org/faostat/en/\#data/FBS (accessed on 22 July 2020).

25. Shine, P.; Scully, T.; Upton, J.; Shalloo, L.; Murphy, M.D. Electricity \& direct water consumption on Irish pasture based dairy farms: A statistical analysis. Appl. Energy 2018, 210, 529-537. [CrossRef]

26. Brugger, M.; Dorsey, B. Water Use and Savings on a Dairy Farm. In Proceedings of the American Society of Agricultural and Biological Engineers (ASABE), St. Joseph, MI, USA, 9-12 July 2006. [CrossRef]

27. Brøgger Rasmussen, J.; Pedersen, J. Electricity and Water Consumption at Milking; Danish Agricultural Advisory Service: Aarhus, Denmark, 2004. 
28. Higham, C.D.D.; Horne, D.; Singh, R.; Scarsbrook, M.R.R.; Kuhn-Sherlock, B.; Scarsbrook, M.R.R. Water use on nonirrigated pasture-based dairy farms:Combining detailed monitoring and modeling to set benchmarks. J. Dairy Sci. 2017, 100, 828-840. [CrossRef]

29. Krauß, M.; Drastig, K.; Prochnow, A.; Rose-Meierhöfer, S.; Kraatz, S. Drinking and cleaning water use in a dairy cow barn. Water 2016, 8, 302. [CrossRef]

30. Shortall, J.; O’Brien, B.; Sleator, R.D.; Upton, J. Daily and seasonal trends of electricity and water use on pasture-based automatic milking dairy farms. J. Dairy Sci. 2018, 101, 1565-1578. [CrossRef]

31. Appuhamy, J.A.D.R.N.; Judy, J.V.V.; Kebreab, E.; Kononoff, P.J.J. Prediction of drinking water intake by dairy cows. J. Dairy Sci. 2016, 99, 1-15. [CrossRef] [PubMed]

32. Cardot, V.; Le Roux, Y.; Jurjanz, S. Drinking behavior of lactating dairy cows and prediction of their water intake. J. Dairy Sci. 2008, 91, 2257-2264. [CrossRef] [PubMed]

33. Robinson, A.D.; Gordon, R.J.; VanderZaag, A.C.; Rennie, T.J.; Osborne, V.R. Usage and attitudes of water conservation on Ontario dairy farms. Prof. Anim. Sci. 2016, 32, 236-242. [CrossRef]

34. Murphy, E.; De Boer, I.J.M.; van Middelaar, C.; Holden, N.; Curran, P.; Upton, J. Predicting fresh water demand on Irish dairy farms using farm data. Clean. Prod. 2017, 166, 58-65. [CrossRef]

35. Shine, P.; Scully, T.; Upton, J.; Murphy, M.D. Multiple linear regression modelling of on-farm direct water and electricity consumption on pasture based dairy farms. Comput. Electron. Agric. 2018, 148, 337-343. [CrossRef]

36. Shine, P.; Murphy, M.D.; Upton, J.; Scully, T. Machine-learning algorithms for predicting on-farm direct water and electricity consumption on pasture based dairy farms. Comput. Electron. Agric. 2018, 150, 74-87. [CrossRef]

37. Castle, M.E.; Thomas, T.P. The water intake of British Friesian cows on rations containing various forages. Anim. Prod. 1975, 20, 181-189. [CrossRef]

38. Little, W.; Shaw, S.R. A note on the individuality of the intake of drinking water by dairy cows. Anim. Prod. 1978, 26, 225-227. [CrossRef]

39. Murphy, M.R.; Davis, C.L.; McCoy, G.C. Factors affecting water consumption by holstein cows in early lactation. J. Dairy Sci. 1983, 66, 35-38. [CrossRef]

40. Stockdale, C.R.; King, K.R. A note on some of the factors that affect the water consumption of lactating dairy cows at pasture. Anim. Prod. 1983, 36, 303-306. [CrossRef]

41. Holter, J.B.; Urban, W.E. Water partitioning and intake prediction in dry and lactating Holstein cows. J. Dairy Sci. 1992, 75, 1472-1479. [CrossRef]

42. Dahlborn, K.; Akerlind, M.; Gustafson, G. Water intake by dairy cows selected for high or low milk-fat percentage when fed two forage to concentrate ratios with hay or silage. Swedish J. Agric. Res. 1998, 28, 167-176.

43. Meyer, U.; Everinghoff, M.; Gädeken, D.; Flachowsky, G. Investigations on the water intake of lactating dairy cows. Livest Prod. Sci. 2004, 90, 117-121. [CrossRef]

44. Khelil-Arfa, H.; Boudon, A.; Maxin, G.; Faverdin, P. Prediction of water intake and excretion flows in Holstein dairy cows under thermoneutral conditions. Animal 2012, 6, 1662-1676. [CrossRef]

45. OMAFRA. Ontario Ministry of Agriculture, Food and Rural Affairs' (OMAFRA) Nutrient Management Software Program. Using NMAN Best Manag Pract 2016. Available online: http://www.omafra.gov.on.ca/ english/nm/nman/nman3.htm (accessed on 21 May 2018).

46. Cuthbertson, E.; Senyshyn, L.; Koppen-Train, S. Milking centre waste management in Ontario. Can. Agric. Eng. 1995, 37, 258.

47. House, H.K.; Hawkins, B.C.; Barkes, B.C. Measuring and Characterizing On-Farm Milking Centre Washwater Volumes. Am. Soc. Agric. Biol. Eng. 2014, 7004, 1-16. [CrossRef]

48. Harner, J.P.; Brouk, M.J.; Potts, J.; Bradford, B.; Smith, J.F.; Hall, S. Scientific data for developing water budgets on a dairy. In Proceedings of the Western Dairy Management Conference, Reno, NV, USA, 6-8 March 2001; pp. 90-104. Available online: http://wdmc.org/2013/Scientific\%20Data\%20for\%20Developing\%20Water\% 20Budgets\%20on\%20a\%20Dairy.pdf (accessed on 2 September 2020).

49. Piquette, S. The Water Use Efficiency of Dairy Farming in Eastern Ontario: A Case Study; Carleton University: Ottawa, ON, Canada, 2015. 
50. DPI Department of Primary Industries. Dairy Shed Water-How Much do You Use? A Comprehensive Guide to Calculating Water Use in the Dairy Shed. 2009; pp. 1-17. Available online: http://agriculture.vic. gov.au/_data/assets/pdf_file/0007/197080/Dairy-shed-water.pdf (accessed on 17 May 2018).

51. Callinan, L.; Ward, R.; Kelstall, B.; McDonald, S.; Eldridge, R.; Williams, J. Dairy Shed Water Use in Victoria: 2009 Analysis 2010. Available online: http://agriculture.vic.gov.au/_data/assets/pdf_file/0003/197085/DairyShed-Water-Use-in-Victoria-2009-Analysis.pdf (accessed on 17 May 2018).

52. Cheung, P.B.; Guilherme, V.; Abe, N.; Propato, M. Night flow analysis and modeling for leakage estimation in a water distribution system. In Integrating Water Systems (CCWI 2010); Taylor \& Francis Group: London, UK, 2010; pp. 509-513.

53. Tabesh, M.; Yekta, A.; Hossein, A. Assessment of real losses in potable water distribution systems: Some recent developments. Water Sci. Technol. Water Supply 2005, 5, 33-40. [CrossRef]

54. Clarke, J.; David, B.; Erdman, R. Nutrient Requirements of Dairy Cattle; National Academy Press: Washington, DC, USA, 2001; pp. 178-183. [CrossRef]

55. Teagasc. National Agri-Environment Conference 2014-Environment Conference 2014 2014:24. Available online: https://www.teagasc.ie/media/website/publications/2014/AgriEnvironment_ Conference2014.pdf (accessed on 2 September 2020).

56. Shine, P.; Upton, J.; Sefeedpari, P.; Murphy, M.D. Energy consumption on dairy farms: A review of monitoring, prediction modelling and analyses. Energies 2020, 13, 1288. [CrossRef]

57. Karlsson, A.E.; Hörndahl, T.; Nordman, R. Energy recover from milk cooling. In Report 401; Agriculture $\mathcal{E}$ Industry; JTI-Swedish Institute of Agricultural and Environmental Engineering: Uppsala, Sweden, 2012.

58. Murphy, M.D.; Upton, J.; O’Mahony, M.J. Rapid milk cooling control with varying water and energy consumption. Biosyst. Eng. 2013, 116, 15-22. [CrossRef]

59. Khan, S.; Abbas, A.; Rana, T.; Jason, C. Dairy Water Use in Australian Dairy Farms: Past Trends and Future Prospects; CSIRO Water for a Healthy Country National Research Flagship: Canberra, Australia, 2010.

60. Ryan, T.; Donworth, J. Teagasc-Milking Facilities. 2012, pp. 125-138. Available online: https://www.teagasc. ie/media/website/animals/dairy/MilkingFacilities.pdf (accessed on 17 May 2018).

61. Ridoutt, B.; Hodges, D. From ISO14046 to water footprint labeling: A case study of indicators applied to milk production in south-eastern Australia. Sci. Total Environ. 2017, 599-600, 14-19. [CrossRef]

62. Stewart, G.; Rout, R. Reasonable Stock Water Requirements: Guidelines for Resource Consent Applications 2007. Available online: https://www.boprc.govt.nz/media/470831/reasonable-stock-water-requirementsguidelines-horizons.pdf (accessed on 2 September 2020).

63. IDF. Bulletin of the International Dairy Federation 479/2015 - A common carbon footprint approach for dairy. Bull. Int. Dairy Fed. 2015, pp. 1-64. Available online: https://www.fil-idf.org/wp-content/uploads/ 2016/09/Bulletin479-2015_A-common-carbon-footprint-approach-for-the-dairy-sector.CAT.pdf (accessed on 2 September 2020).

64. Sjaunja, L.O.; Baevre, L.; Junkkarinen, L.; Pedersen, J.; Setälä, J. A Nordic proposal for an energy corrected milk (ECM) formula. In Proceedings of the 27th Session of International Committee for Recording the Productivity of Milk Animals, Paris, France, 2-6 July 1990; pp. 156-157.

(C) 2020 by the authors. Licensee MDPI, Basel, Switzerland. This article is an open access article distributed under the terms and conditions of the Creative Commons Attribution (CC BY) license (http://creativecommons.org/licenses/by/4.0/). 